\title{
Transfigurações Cívicas: \\ A terra fluminense, Contos pátrios e A pátria brasileira ${ }^{\wedge}$
}

\section{Cleber Santos Vieira ${ }^{2}$}

\section{Resumo}

Este artigo analisa temas, títulos e abordagens de alguns contos publicados por Olavo Bilac e Coelho Neto no livro A terra fluminense (1898) que, sob nova roupagem, foram relançados em outras duas publicações dos mesmos autores - Contos pátrios (1904) e A pátria brasileira (1909). Busca-se demonstrar que os textos foram transfigurados, deixando de representar uma face regional da educação cívica para serem imortalizados enquanto expressões do civismo brasileiro.

\section{Palavras-chave}

Livro de leitura, educação cívica, Primeira República

1 Esse artigo é parte da tese de doutorado Entre as coisas do mundo e o mundo dos livros: prefácios cívicos e impressos escolares no Brasil Republicano defendida junto ao Programa de Pós-Graduação da Faculdade de Educação da Universidade de São Paulo (FE/USP), sob orientação do Prof. Dr. Nelson Schapochnik. Versão preliminar desse texto foi apresentada como comunicação oral durante $o$ Simpósio Internacional - Livro Didático: Educação e História, realizado de 05 a 08 de novembro de 2007 na FE/USP.

2 Programa de Mestrado em Educação da Universidade São Francisco, Itatiba, São Paulo. E-mail: clebersvieira@yahoo.com.br 


\title{
Civic Transfigurations: \\ A terra fluminense, Contos pátrios and A pátria brasileira
}

\section{Cleber Santos Vieira}

\begin{abstract}
The article analyses themes, titles and approaches present in short stories published by Olavo Bilac and Coelho Neto in the book $A$ terra fluminense [The Fluminense Land] (1898), which appeared in restyled form as two other books by the same authors, Contos pátrios [Short Stories of the Fatherland] (1904) and A pátria brasileira [The Brazilian Fatherland] (1909). The intent is to demonstrate that the texts were transfigured, ceasing to represent a regional face of civic education and becoming immortalized as expressions of Brazilian civism.
\end{abstract}

Keywords

Reading Book, Civic Education, First Republic 


$$
G^{\circ}
$$


projetam-se como desdobramento da produção nacional destinada ao ensino elementar que, iniciada no Império, ganhou impulso decisivo no projeto educacional republicano. Os valores responsáveis pela uniformização do modelo de sociedade pretendido passavam pela organização do sistema escolar, na adequação de níveis de ensino e na adoção de livro de leitura único.

O presente artigo busca demonstrar outras possibilidades analíticas sobre esses mesmos objetos. A abordagem incide nos procedimentos empregados pelos autores dos livros analisados ao transferirem temas, textos e prefácios produzidos a partir de referências regionais para produções destinadas a um público escolar de feição nacional. O enfoque desdobra-se na análise genealógica dos textos. O que não implica pensar A terrafluminense, Contos pátrios e A pátria brasileira enquanto discursos lineares, mas enquanto elementos do discurso cívico que, com sutis mudanças, transfiguraram o foco narrativo.

Parte-se do pressuposto de que o prefácio, os textos e os temas desenvolvidos por Bilac e Coelho Neto em A terra fluminense constituem o discurso cívico preliminar do conjunto da produção didática da dupla. Como tal, anteciparam abordagens de cunho patriótico ou de caráter nacional que no início do século XX, alcançaram notoriedade em livros de maior envergadura comercial: Contos pátrios, A pátria brasileira. Verificou-se que a preocupação republicana de formar cidadãos foi assegurada, muitas vezes, pelo enquadramento de textos e títulos ao imaginário republicano delineado por autores, editoras e Estado. Para viabilizar a reflexão, consideramos, inicialmente, o prefácio como categoria de análise do livro na perspectiva formulada por Gérard Genette, ou seja, "toda especie de texto liminar (preliminar o pos liminar) autoral o alógrafo que constituye un discurso producido a propósito del texto que

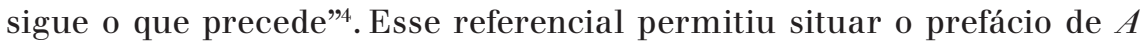
terra fluminense como ponto de partida da análise abrindo, desse modo, um diálogo mais amplo com outros estudos acadêmicos sobre os livros de civismo na primeira república.

manual didático a partir de Alain Choppin. No Brasil, as teses de Circe Bittencourt [Livro didático e conhecimento histórico: uma história do saber escolar. São Paulo, 1993 (Tese de Doutorado, FFLCH-USP)] e Kazumi Munakata (Produzindo livros didáticos e paradidáticos. São Paulo, 1997 (Tese de Doutorado, PUC-SP) são expressões desse processo.

4 GENNETE, Gérard. Umbrales. México: Siglo Veintiuno Editores, 2ool. p.137. Outros autores enquadram prefácios na categoria protocolos de leitura. Ver: SHOLES, Robert. Protocolos de leitura. Lisboa: Edições 70, 1991. CHARTIER, Roger. A história cultural: entre práticas e representações. Lisboa: Difel, 1990. DERRIDA, Jacques. La dissémination. Paris: Éd. Du Seuil,1972. 
Marisa Lajolo, no estudo sobre Bilac e a literatura escolar na primeira república, fala, em dois momentos, da importância do prefácio do livro Poesias infantis e da "Advertência" de Através do Brasil para compreender a função do livro de leitura na formação cívica dos estudantes: "a importância de um relacionamento afetivo aluno/texto, por exemplo, já fora intuída, explicada e prometida por Bilac e Bomfim no prefácio de Através do Brasil"5. Mais adiante, comenta: "Contos pátrios é de 1904, mesmo ano das Poesias infantis, em cujo prefácio Bilac frisa suas preocupações didáticas. Parece justo, portanto, estender tais objetivos a todos os seus textos didáticos produzidos na época." ${ }^{\circ}$

As proposições estão absolutamente corretas. Bilac afirma e reafirma que o sentimento nacional não pode ser despertado apenas pelo caminho da razão, mas principalmente pelo coração. Afirma e reafirma também que a intenção do livro não é compor uma obra de arte, mas contribuir, por meio da literatura, para a educação cívica e moral das crianças brasileiras.

A questão é de outra ordem: os protocolos de leitura de Através do Brasil e Poesias infantis são formações discursivas originais? Podem ser estendidas a outras obras porque constituem um marco inaugural na obra de Bilac, no sentido de apresentarem as intenções gerais da produção didática dos autores?

Considerando a categoria analítica denominada formação discursiva por Michel Foucault ${ }^{7}$, a resposta é não. A Advertência e o Prefácio das obras acima citadas redimensionaram o próprio discurso preliminar na produção didática de civismo, contido no protocolo de leitura que acompanhou o conjunto de textos dedicados à formação cívica do povo fluminense. O civismo praticado nas publicações do início do século XX seriam pontos amarrados a um sistema de remissões a outros livros. São recomeços e ocultações: recomeçam uma prática cívica de matriz republicana e ocultam a transfiguração operada no objeto do discurso cívico regional.

O primeiro aspecto a ser considerado é de que o esquecimento de A terra fluminense nos conduz a lembrar as semelhanças entre o prefácio de 1898 e o de Poesias infantis. No primeiro caso, o manual é precedido do seguinte discurso:

5 LAJOLO, Marisa. Usos e abusos da literatura na escola: Bilac e a literatura escolar na República Velha. Rio de Janeiro: Globo, 1992 . p.25.

6 Idem. Ibidem, p.61.

7 FOUCAULT, Michel. Arqueologia do saber. Rio de Janeiro: Forense Universitária, 1986. p.25 e segs. 
Neste livro, a História e a Fantasia andam unidas; e procuramos aproveitar os assuntos, de maneira que pudessem eles interessar não somente a inteligência, mas também o coração das crianças. $[\ldots]$

Quisemos fugir da aridez, da forma complicada e da banalidade, ao mesmo tempo; dirão os competentes se saímos bem na empresa. E se nessas poucas páginas sinceras a criança aprender a amar a sua pátria, estarão satisfeitos os desejos de Coelho Neto e Olavo Bilac. ${ }^{8}$

No prefácio de Poesias infantis a conclusão de Bilac é a seguinte:

Não sei se consegui vencer todas essas dificuldades. O livro aqui está. É um livro em que não há os animais que falam, nem as fadas que protegem ou perseguem crianças, nem as feiticeiras que entram pelos buracos das fechaduras; há aqui descrições da natureza, cenas de família, hinos ao trabalho, à fé, ao dever; alusões ligeiras à história da pátria, pequenos contos em que a bondade é louvada e premiada.

Quanto ao estilo do livro, que os competentes julguem. Fiz o possível para não escrever de maneira que parecesse fútil demais às crianças.

Se a tentativa falhar, restar-me-á o consolo de ter feito um esforço digno. Quis dar à literatura escolar do Brasil um livro que lhe faltava. ${ }^{9}$

Em segundo lugar, há de se destacar que no prefácio de $A$ terra fluminense, livro de educação cívica para crianças, Coelho Neto e Olavo Bilac declararam a finalidade desta publicação, afirmando: "anima-nos a convicção de que não poupamos esforços em escrever um livro original, em que a criança encontrará, sumariamente indicada, toda a vida política, toda a vida moral e toda a vida comercial da Terra Fluminense."10. E em um excerto posterior acrescentaram "a grande e a pequena lavoura, as origens da civilização e do trabalho, as indústrias, os aspectos da natureza, o comércio, a formação dos núcleos geradores de progresso, a evolução política, o passado, o presente e o futuro do Estado do Rio de Janeiro, estão parecem-nos, resumida e claramente, contidas nesta obra" ${ }^{11}$.

8 BILAC, O.; COELHO NETO. A terra fluminense. Rio de Janeiro: Imprensa Nacional, 1898, p.oz.

9 Idem. Ao leitor. Apud: LAJOLO, Marisa. Um Brasil para crianças: para conhecer a literatura infantil brasileira: autores e textos. 4. ed. São Paulo: Global, 1986. p. 273-274.

10 Idem. A terrafluminense. op. cit., p.oz. Registre-se o trabalho pioneiro de Marisa Lajolo. Usos e abusos da literatura na escola: Bilac e a literatura escolar na República Velha. op. cit., 1992.

11 BILAC, O.; COELHO NETO. A terrafluminense. op. cit. 
O discurso preliminar revela o lugar, o momento, os destinatários e os vínculos históricos que recobriram a produção do livro. Nesse sentido, as afirmações de Bilac e Coelho Neto não deixam margem a qualquer tipo de questionamento quanto ao caráter regional do livro $A$ terra fluminense. Trata-se de um impresso escolar declaradamente escrito com a finalidade de despertar o amor à pátria fluminense.

As semelhanças dos discursos e anterioridade de $A$ terrafluminense permitiram indagar o conjunto dos livros elevando a análise à modalidade de crítica textual. Conduziram, então, o pensamento sobre o alcance das interpretações que situam os livros A pátria brasileira e Contos pátrios como expressões de um engajamento patriótico completamente associado à comunidade política imaginada. Textos como O lenhador, Pátria nova, Uma vida, Civilização e Quinze de novembro, sob títulos diferentes, foram produzidos sob o prisma do patriotismo provinciano, que visava potencializar a educação cívica do estudante fluminense.

Todavia, foram reconhecidos anos mais tarde em Contos pátrios e A pátria Brasileira, já quando prevalecia a concepção de educação cívica de feições nacionalistas. Alcançaram, inclusive, o status de best sellers. Contos pátrios $^{12}$, por exemplo, nos sessenta e quatro anos de edições e reedições, a Livraria Francisco Alves vendeu cerca de 250 mil exemplares ${ }^{13}$. Para isso, houve a conjunção de múltiplos fatores estruturados em torno da história do livro didático e do livro de leitura no início do século XX.

É importante lembrar que Olavo Bilac e Coelho Neto participaram ativamente das mudanças ocorridas nas décadas situadas entre a eclosão do movimento republicano (1870) e o término da Primeira Guerra Mundial (1918). Em suas biografias, inscrevem-se marcas de intelectuais politicamente engajados. No Rio de Janeiro, logo após a Proclamação da República, Coelho Neto assumiu as funções de secretário de governo e dos negócios

12 Os biógrafos de Bilac registram dados contraditórios acerca do ano de produção e publicação do livro. Leonardo Arroyo afirma que "Contos pátrios e Poesias infantis tiveram sua propriedade adquirida pela Livraria Francisco Alves no ano de 1896. A data da primeira edição é ignorada, assim como onde foram impressos esses dois volumes. A segunda edição desses livros, porém, é de 1906 e impressa em Paris.” (ARROYO, Leonardo. Olavo Bilac. 2. ed. São Paulo: Melhoramentos. s/d. p.46) Já Marisa Lajolo, baseada em E. Pontes, outro biógrafo de Bilac, data em 1904 a publicação dos dois volumes escritos em circunstância pitoresca: endividados, Coelho Neto e Olavo Bilac "teriam ido à Editora Francisco Alves, dando ao livreiro a opção: o que lhe interessa mais? Um romance de aventuras, ou uma antologia de contos infanto-juvenis? Escolhida a segunda sugestão, quatro dias depois tinha o editor em mãos o original de Contos pátrios".

13 LAJOLO, Marisa. Usos e abusos da literatura na escola. op. cit. p.61. 
do Estado, mesma instituição onde Olavo Bilac, em 1891, foi nomeado secretário do interior. Em 1906, durante a turbulenta gestão Pereira Passos na Capital Federal, Olavo Bilac tornou-se o secretário do prefeito. Por sua vez, Coelho Neto ocupou uma Câmara Federal eleito deputado pelo Estado do Maranhão em 1909 e reconduzido em 1917. Já Olavo Bilac, abolicionista e republicano ficou conhecido na vida política pelo crucial papel desempenhado nas campanhas públicas em defesa do serviço militar obrigatório, da gratuidade do ensino e, principalmente, pela intensa participação nas atividades desenvolvidas pela Liga de Defesa Nacional.

A integração a esta rede de sociabilidade, porém, foi apenas um dos fatores que proporcionaram a repercussão do livro e dos autores. Há de se destacar, ainda, a incorporação de Olavo Bilac e Coelho Neto a outros segmentos da cultura letrada que favoreceram a produção e circulação de livros didáticos. Com efeito, foi decisiva a incorporação de Bilac e Coelho Neto ao repertório de autores contratados pelo empreendedor Francisco Alves. Conforme indicou Halwell, a expansão da Editora Francisco Alves no mercado de livros didáticos contou com aguçada sensibilidade do editor em recrutar potenciais autores, inclusive de outras editoras ${ }^{14}$. Depois, é preciso considerar que a fortíssima repercussão comercial dos livros foi favorecida pelo papel ocupado pelo livro de leitura no ensino primário no decorrer das primeiras décadas do novo regime. Ampliaram-se os espaços do conteúdo e de temas nacionalistas. Como explicou Circe Bittencourt "as mudanças nos programas da escola elementar, durante a fase republicana, eram sustentadas por propostas que conferiam ao livro de leitura proeminência sobre os demais." ${ }^{5}$ Articulado a esse processo, cite-se ainda a expansão do sistema público de ensino operacionalizado sob o regime republicano tendo São Paulo como centro irradiador. Tal fato, facilitou a circulação dos livros, considerados apropriados para uniformizar a formação dos estudantes, instituições e modelos de ensino controlados pelo Estado ${ }^{16}$.

A terra fluminense, não fez parte do circuito de produção didática de circulação nacional, sendo, inclusive, um manual esquecido, quando muito é citado como parte da bibliografia dos autores. Nesse sentido, a análise dos textos de Bilac e Coelho Neto permitiu uma viagem pelo mundo das transfigurações cívicas operadas no deslocamento do patriotismo regional em direção ao nacional. Note-se: esta operação transfigurativa

14. HALLEWELL, Laurence. O livro no Brasil. 2. ed. São Paulo: Edusp. 2005. p. 280-294.

15 BITTENCOURT, Circe. Livro Didático e conhecimento histórico: uma história do saber escolar. São Paulo. (Tese de Doutorado, USP), 1993.

16 RAZZINI, Márcia de Paula Gregório. Livro didático e expansão escolar em São Paulo. Lingua Escrita, n. 1, p. 19-43, jan/abril, 2007. 
ocorreu deixando vestígios, cuja percepção foi possível através da microscópica observação da estrutura interna dos textos. No centro deste processo, Bilac e Coelho Neto, amantes da pátria fluminense, tornam-se expoentes do civismo brasileiro. Morrem os autores regionais e nascem os grandes literatos da comunidade política imaginada. A nossa tarefa, então, a partir desse ponto, foi "localizar o espaço deixado vazio pelo desaparecimento do autor, seguir de perto a repartição das lacunas e das fissuras e perscrutar os espaços, as funções livres que esse desaparecimento deixa a descoberto" ${ }^{\prime \prime}$.

Seria possível conjeturar sobre a importância dos acontecimentos históricos pertinentes à proclamação da República transcorridos na Capital Federal. O Rio de Janeiro constituiria, então, fonte de inspiração ou modelo exemplar do culto à comunidade política recém imaginada como república. Porém, na conclusão do discurso preliminar, Bilac e Coelho Neto revelaram o desejo de ensinar as crianças a amar sua pátria, indicando que ao designar "terra em que se nasceu" a palavra pátria ainda apresentava sentidos ambivalentes. Ou seja, no final do século XIX, os sentidos de pátria abarcavam tanto a província quanto o país. A maneira pela qual Olavo Bilac transitou por essa indeterminação foi de maneira bastante elástica. Todavia, para além das conexões regionais e nacionais, na intimidade, Olavo Bilac postulava outro conceito de patriotismo. Conforme registro de Elias Thomé Saliba, em carta endereçada de Paris a Coelho Neto em 1904, Bilac dizia: "aos vinte e cinco anos, quando pensava que tinha de sair de Paris chorava de raiva. E hoje não posso passar aqui quatro meses sem ter saudade da porcaria, do mijo, da estupidez, do mexerico, da safadeza da pátria. [...] O patriotismo é como o reumatismo, é um achaque da velhice."18

A plasticidade e ambigüidade da idéia de patriotismo sincronizavam-se, evidentemente, aos vários movimentos nacionalistas que, por todas as partes, quebravam as fronteiras provincianas da idéia de pátria, relançando-a como expressão das comunidades nacionais imaginadas ${ }^{19}$. Dicionários de relevante circulação nacional atestaram o caos. Foi o caso de Caldas Aullete, que, na edição de 1883, manifestava a transição histórica do termo e, portanto, as ambigüidades latentes entre amar a

17 FOUCAULT, Michel. O que é um autor? Portugal: Passagens, 1992. p .41.

18 Apud: SAlIBA, Elias Thomé. Raizes do riso. A representação humorística na História brasileira: da Belle Époque aos primeiros tempos do rádio. São Paulo: Companhia das Letras, 2002. p. 194.

19 Refiro-me ao conceito de nação como "comunidade política imaginada" na acepção proposta por: ANDERSON, Benedict. Comunidades imaginadas. Lisboa: Edições7o, 1991. 
província e amar o Brasil: Pátria - "país ou estado em que cada um nasceu, e ao qual pertence como cidadão. Província, cidade, vila, etc. em que se nasceu; terra natal."20

Em A terra fluminense, o texto "A República”, explicita a confusão em torno da idéia de patriotismo de coloração fluminense e de temas latentes na nação republicana:

\section{A República}

Era o dia 15 de novembro de 1889.

Em Niterói, na parte das barcas Ferry, aglomerava-se a multidão ansiosa. Sabia-se que o exército nacional, obedecendo as ordens do glorioso marechal Deodoro da Fonseca, estava no Campo da Aclamação em linha de batalha cercando o quartel general.

Dizia-se que a República havia sido proclamada e de instante em instante crescia a ansiedade dos que esperavam notícias. As barcas que partiam iam cheias de gente; os comentários se multiplicavam; havia incrédulos que achavam absurdo o boato; mas havia também quem achasse natural a confirmação daquilo que os bons patriotas esperavam havia tanto tempo.

As três horas da tarde, de uma barca que chegava, saltou um moço, dando vivas à República a Deodoro e a Benjamin Constant. E foi dos seus lábios que todos ouviram a grande notícia. O governo do Império capitulara. Deodoro aclamado pelo povo e pela tropa, era vencedor: os populares reunidos no paço da câmara municipal acabavam de declarar estabelecido o regime republicano. Ouvindo isso a multidão se agitou com entusiasmo, e um só agito delirante saiu de todas as bocas.

- Viva a República!

Então um menino, que acompanhando o pai, assistia, àquela cena, perguntou:

- O que é isto papai? Que é a república?

O pai disse-lhe com as faces coroadas de júbilo e os olhos flamejantes de orgulho:

- A República, meu filho, é a liberdade! A República é a felicidade do povo. Agora, a tua terra não é mais governada, por um senhor. Agora, a tua pátria não é mais propriedade de uma família real..., agora, o Brasil é verdadeiramente uma nação digna de estar ao

20 AULlete, F. L. Caldas. Dicionário contemporâneo da língua portugueza. Lisboa: Imprensa Nacional, 1883 . 
lado das irmãs americanas... A república vai acabar com os privilégios de trono: agora vamos ser governados por um de nós, livremente escolhido por nós! A república, meu filho, é o governo do povo pelo povo... a República é a nossa carta de alforria... Grita também meu filho, grita também!

E a criança, batendo as mãos no ar, gritou com alegria.

-Viva a República. ${ }^{21}$

Logo no segundo parágrafo, a descrição do cotidiano tranqüilo em Niterói - capital da província do Rio de Janeiro e não do Brasil, vale lembrar - realça o cenário onde o povo reconhece a República. Do aglomerado de pessoas na ponte de acesso às barcas Ferry partia um misto de opiniões sobre a proclamação. Comentários sobre a queda do império em tom negativo logo são qualificados como incrédulos; aqueles que reverberam o ato de 15 de novembro como natural, inevitável, foram aclamados como bons patriotas; entre os opostos parece existir uma multidão de espectadores que, sem paixões para nenhum dos lados, tocam a vida e, acidentalmente, aguardam o desdobrar dos boatos. Temos, então, uma narrativa que constrói a história da proclamação da República como um campo de possibilidades. Há espaço para incertezas, dúvidas e mesmo descrenças em relação ao advento: "sabia-se que o exército nacional", "dizia-se que a República”, "havia quem achasse"... Porém, suspeitas sobre a mudança de regime político logo se confirmaram pelas palavras de um anônimo passageiro.

A distância entre a Capital Federal e a capital fluminense personifica a própria distância entre povo e República. Os personagens que protagonizam o povo não participam e não presenciam diretamente o ato de proclamação, apenas tomam conhecimento do desenrolar histórico que se passa do outro lado da baía. A interligação é proporcionada no momento em que um anônimo personagem anuncia as boas novas da capital. Comentários e discussões que antes enunciavam possibilidades históricas dissipam-se. A República torna-se, então, incontestável, inclusive para os transeuntes ocupados e preocupados com seus afazeres cotidianos junto às barcas Ferry. Na República proclamada em Niterói, marechal Deodoro da Fonseca e Benjamim Constant não têm voz ativa, sendo a república saudada e aclamada por vozes populares. Mas o que era dúvida, descrença e incerteza transforma-se em fato absoluto, desconhecido apenas às gerações mais jovens. Daí o tom professoral pelo qual o pai responde ao questionamento do filho. "Viva a república!", gritava a multidão. “Mas o que é república?” Perguntou o filho. E o pai respondeu: "é a carta de alforria da nação...”

21 BILAC, O.; COELHO NETTO. A terra fluminense. op.cit. p. 65-66. 
Publicado onze anos depois, o conto Quinze de novembro representa o mesmo episódio fundador da República Brasileira. Dessa vez, porém, Bilac e Coelho Neto miram a pátria de fronteiras nacionais, abandonando os limites regionais que outrora circunscreveram o discurso cívico de $A$ terrafluminense. Enquanto a caricatura cívica temperada por um patriotismo regional marcou o conto "A República", em A pátria brasileira, como o próprio título sugere, o tema foi relançado em dimensões nacionais. Esta dimensão é sugerida logo no título, "Quinze de novembro", que já desponta na condição de data cívica de relevância nacional.

Além do tema, outros personagens e fatores assemelham-se: povo, Constant e Deodoro. Todavia, para além das coincidências, os contos narram acontecimentos transcorridos em turnos diferentes. Em Niterói, a notícia da Proclamação da República chegou juntamente com a embarcação originária da Capital Federal, que atracou na ponte das barcas Ferry às três horas da tarde. Na Capital Federal, o evento iniciou-se ao "amanhecer do mês balsâmico". As ações dos protagonistas sofreram verdadeiras transfigurações. O povo, substrato político da comunidade imaginada em bases republicanas, logo recebe o adjetivo de trabalhador, que, saindo dos subúrbios, observa o movimento das tropas republicanas no campo da Aclamação. O "dizia-se que as tropas" cede espaço para o espanto vivaz dos populares que espacialmente se aproximam dos militares. O povo, aqui, é descrito como homogêneo no seu posicionamento em relação ao advento republicano. Não há divergências, expectativas, desconhecimento ou descrença quanto à natureza da República. A participação popular inicia-se a caminho do trabalho, quando, mesmo espantado, o povo se identifica com os soldados amotinados e, a seguir, acompanha o coro antimonárquico: “viva a República!” Em outro momento, a aclamação popular reforça o advento republicano, confirmando aos ministros presos e aos marinheiros reticentes que o povo estava ao lado da República.

Nos onze anos que separam a publicação de $A$ terrafluminense da primeira edição de $A$ pátria brasileira, Bilac e Coelho Neto atravessam a baía da Guanabara, chegam à antiga capital do Império e dão vivas à República pela boca de Deodoro. A participação do Marechal descrito no texto Quinze de novembro não aparece pela voz de um ilustre desconhecido, como o anunciado em $A$ terrafluminense, mas ele mesmo parece ter em suas mãos as regras do processo que desencadeou a derrubada de D. Pedro II.

Em A terra fluminense, o ato da Proclamação corresponde à completa transformação histórica: o fim da Monarquia, o encontro da sociedade brasileira com as nações americanas, o governo do povo. Questionado sobre o que é a República, o pai não hesita em, com entusiasmo, coroar o novo regime. Mas a pátria que segue o caminho do progresso é a pátria 
fluminense e a ela cabe a tarefa de preparar os estudantes ao triunfo final, como é possível entrever no epílogo do livro:

O Futuro

\section{HINO ESCOLAR}

Vamos, fugindo de um passado escuro,

Pátria querida, às glorias do Futuro

Para teu nome e teu porvir cantar,

Num hino vasto que o triunfo exprima,

Falem teus campos que o trabalho anima,

Teus verdes em flores, e o futuro espera...

Teus verdes montes e teu largo mar!

Conduza a vossa mocidade,

Irmãos! Este hino triunfal!

Avante em busca da verdade.

Luz imortal!

A mocidade é como a primavera:

Abre-se em flores, e o futuro espera...

A mocidade é da esperança irmã!

A nova Pátria vive em nossos peitos :

Das flores de hoje hão-de sair, perfeitos,

Os frutos de amanhã!

Conduza a vossa mocidade, Irmãos! Este hino triunfal!

Avante em busca da verdade.

Luz imortal!

A mocidade é como as nebulosas,

Que, em confusão, nas amplidões radiosas, Guardam milhões de estrelas, a dormir...

Sairão do teu seio, ó mocidade,

Ó, nebulosa de uma nova idade,

Os astros do porvir...

Conduza a vossa mocidade, Irmãos! Este hino triunfal!

Avante em busca da verdade.

Luz imortal! ${ }^{22}$ 
A Pátria brasileira dá continuidade à perspectiva inaugurada pelo discurso preliminar, isto é, no texto "A República", mas parece inserir um dado de probabilidade quanto ao sucesso da república:

[...] Começou sob magníficos auspícios; e, para que ela se torne grande e forte, urge que todos os que nasceram à sombra do seu pavilhão glorioso, num esforço comum e patriótico, trabalhem pela sua prosperidade, e não se recusem a defendê-la, no momento em que, acenando aos filhos, ela lhes pedir o sacrifício supremo do sangue. ${ }^{25}$

Trabalhar na comparação de dois contos sobre um mesmo episódio, publicados em contextos diferentes, não é suficiente para demonstrar o poder alquímico dos príncipes literários. No sentido de ampliar o escopo argumentativo, contribuirá a análise de três passagens de um dos contos lançados em A terra fluminense e relançado em Contos pátrios. Motivados pelo federalismo republicano, redigiram um texto no qual enlaçavam a história do Rio de Janeiro aos destinos da civilização ocidental. Deram a ele o nome Vida Civilizada e começava assim:

A civilização, que é a difusão das riquezas materiais, intelectuais e morais, não pode nunca, sem transição, sem um longo trabalho de reforma paciente, tomar conta de um país. Para que ela floresça, é necessário que o moroso passar dos séculos vá apurando as gerações. Se hoje a Terra Fluminense ${ }^{24}$ prospera, civilizada e forte, foi necessário para isso o esforço coletivo e anônimo das gerações que passaram. ${ }^{25}$

Coerentes com o propósito de despertar o espírito cívico dos estudantes, enriqueceram o texto com dados e informações que permitissem ao leitor atestar e comparar a vida civilizada no Rio de Janeiro no final do século XIX com o passado considerado selvagem e bárbaro. Anunciam, então, a existência do transporte ferroviário na vida social dos fluminenses como uma das provas que confirmavam o encadeamento da terra fluminense à sociedade moderna:

23 Idem. A pátria brasileira. Rio de Janeiro: São Paulo: Francisco Alves, 1909. p.282. (Utilizo a 26a edição publicada pela Editora Francisco Alves em 1939.)

24. Grifo do autor.

25 BILAC, O.; COELHO NETO. A terra fluminense. op. cit., p. 55 . 
De extremo a extremo do país, a civilização estendeu essa ramificação prodigiosa: dos troncos centrais partem os galhos, dos galhos partem as ramadas, e de ano em ano troncos se fixam no solo, expandindo em linhas várias, que vão de quilômetro em quilômetro ocupando todas as zonas povoadas ou por povoar. Trinta e três linhas, servindo mais de duzentas estações levam a vida e o progresso do litoral ao centro, e voltam carregando os frutos do trabalho. ${ }^{26}$

No trecho final, a preocupação em expor ao leitor a separação temporal entre civilização e selvageria/barbárie é ainda mais incisiva:

Lembra-te de novo do tempo em que as tribos viviam por aqui nuas e sem leis e do tempo em que Cunhambebe, o feroz cacique, dominava com suas canoas de guerra todo litoral do Rio de Janeiro; lembra-te das épocas em que somente os braços dos pobres cativos exploravam a terra; - e mede a extraordinária extensão do progresso feito. ${ }^{27}$

Pode-se ler Vida civilizada como verdadeiro atestado de óbito da população indígena. A lembrança do modus vivendi indígena funciona como mecanismo diluidor da memória, portanto, que fabrica o esquecimento. As comunidades indígenas e seu líder são desumanizados: ferozes, pelados e sem lei. Essas qualidades animais são empregadas para esquecer um tempo bárbaro e lembrar que o progresso já passara pelo Rio de Janeiro, que a velocidade das locomotivas apagara qualquer vestígio do tempo das rudimentares canoas de guerra.

mas bem depressa a locomotiva heroicamente trepando a serra, suprimiu a fadiga de ascensão a pé ou à cavalo: em 1882, a estrada de ferro Grão-Pará começou a ser prolongada até Petrópolis. E à Pátria Fluminense coube a glória de ter sido a parte do Brasil em que primeiro se assentou o verdadeiro alicerce do progresso comercial e industrial - a via férrea, que suprimiu as distâncias, estreitando as comunicações do trabalho ${ }^{28}$

As linhas ferroviárias e telegráficas que remodelaram a paisagem do Rio de Janeiro pelos símbolos do progresso estenderam-se para

26 Idem, ibidem, p.56.

27 Idem, ibidem, p.58.

28 Idem, ibidem, p.22. 
o resto do país. Bilac e Coelho Neto não perderam tempo: embarcaram nesta locomotiva levando na bagagem as representações cívicas da modernidade para outros estados brasileiros. Mas, antes, lembraram-se de remover dados, informações, palavras, frases e, é claro, o título do texto que originariamente descrevia a história do Rio de Janeiro direcionada para a educação cívica. Esqueceram-se, porém, que, no cemitério dos livros, há sempre espaço para novas sepulturas. E para lembrarmos de Contos pátrios e A pátria brasileira como best sellers da literatura cívica brasileira, foi preciso esquecer as artimanhas literárias, lingüísticas e editorias de que seus autores lançaram mão, ofuscando A terrafluminense como discurso preliminar.

O que recebeu o título de Vida civilizada, em A terra fluminense, em um sobressalto patriótico transfigurou-se em A civilização, incluído nos Contos pátrios. Novos personagens entraram em cena. O conto, antes narrado na terceira pessoa, assume a forma de diálogo entre uma criança de nome Otávio e seu pai. A vida civilizada iniciava-se com uma robusta introdução:

[...] Uma noite, toda a família reunida em torno da grande mesa da sala de jantar, passava calmamente o serão. Otávio, inclinado sobre as páginas de um livro, contemplava as gravuras, e lia com interesse as linhas, em que se narravam longas viagens arriscadas, por terras e mares, na África, na Ásia e nas regiões geladas dos pólos.

De repente, o menino levantou os olhos do livro, e perguntou:

- Papai, que quer dizer "Civilização"?

- Por que pergunta isso Octavio?

- Porque está escrito neste livro que os exploradores da Ásia, da África e dos pólos têm o propósito de levar a civilização a essas regiões... então os homens que lá vivem não são homens como nós?

- São homens como nós, meu filho, mas não são civilizados como nós somos...

E, com paciência e carinho, o pai de Otávio começou explicar-lhe o que é civilização:

- A civilização, que é a difusão... ${ }^{29}$

A técnica da pergunta como instrumento de reescrita do texto foi empregada em outros dois momentos. A exposição das características da

29 BILAC, O.; COELHO NETO. Contos pátrios. 1904. p. 225. (Utilizo a 43a edição publicada pela Editora Francisco Alves em 1956.) 
civilização é interrompida no instante em que o pai menciona a palavra escola. Otávio indaga: a escola também é fruto da civilização, papai? E segue toda a descrição das modernas técnicas de ensino, o uso de recursos didáticos e reprovação dos castigos físicos. Tudo retocado pelas mãos do progresso. A narrativa é novamente interrompida quando o menino manifesta dúvida quanto à finitude desses avanços: e esse progresso é completo? A isso o pai responde dizendo que a civilização e o progresso são frutos do trabalho, naquela junção Pátria, Civilização e Trabalho ${ }^{50}$.

Se a inserção dos diálogos alterou o estilo do texto original, a supressão de referências explícitas ao Rio de Janeiro permitiu que a Vida civilizada, representação cívica da terra fluminense, se tornasse representação cívica do Brasil-nação. Vejamos, então, como ficaram os trechos acima comentados na versão publicada em Contos pátrios.

[...] A civilização, que é a difusão das riquezas materiais, intelectuais e morais, não pode nunca, sem um longo trabalho de reforma paciente, tomar conta de um país. Para que um povo tenha civilização, é necessário que o moroso passar dos séculos vá aperfeiçoando o caráter do povo. Assim, se a terra brasileira ${ }^{31}$ é hoje próspera e forte, foi necessário para isso o esforço coletivo e anônimo das gerações que se tem sucedido. ${ }^{32}$

A sutileza com que terra fluminense foi transformada em terra brasileira revela-se também na fundamentação dos argumentos pró-civilização. Exemplo disso são os dados referentes ao crescimento populacional, visto como ponto vantajoso, pois ocupava e desbravava os espaços geográficos, antes abandonados aos minguados grupos indígenas. $\mathrm{O}$ texto original atestava informações sobre os habitantes do Rio de Janeiro: "[...] Compara esses tempos com o tempo de agora. Vê agora a tua terra ${ }^{33}$ coberta de uma população de mais de um milhão de almas novas" ${ }^{34}$.

A versão publicada no início do século XX atualizava os dados, mirando, porém, o contingente populacional brasileiro: "Compara esses

zo O trinômio Pátria, Civilização e Trabalho foi explorado por BITTENCOURT, Circe. Pátria, civilização e trabalho: o ensino de história nas escolas paulistas (1917-1939). São Paulo: Loyola, 1990.

31 Grifo do autor.

32 BILAC, O.; COELHO NETO. Contos pátrios. op. cit., p. 226.

33 Grifo do autor.

34. BILAC, O.; COELHO NETO. A terra fluminense. op. cit., p. 56 
tempos com o tempo de agora! Vê como a terra brasileira ${ }^{35}$ está coberta de uma população de quarenta milhões de homens" ${ }^{36}$.

Sem delongas, ainda tendo Vida civilizada e Civilização como objeto de análise, alguns trechos do texto original simplesmente desapareceram. O mais provável é que as supressões tenham sido motivadas em função da demasiada identificação das passagens com aspectos da história regional. São eles:

[...] Trinta e três linhas, servindo mais de duzentas estações levam a vida e o progresso do litoral ao centro, e voltam, carregando os produtos do trabalho. ${ }^{37}$

$[\ldots]$

Lembra-te de novo do tempo em que as tribos viviam por aqui nuas e sem leis e do tempo em que Cunhambebe, o feroz cacique, dominava com suas canoas de guerra todo litoral do Rio de Janeiro; lembra-te das épocas em que somente os braços dos pobres cativos exploravam a terra; - e mede a extraordinária extensão do progresso feito. ${ }^{38}$

O tempo parece ter decantado algumas das linhas suprimidas. O personagem Cunhambebe, outrora vilão do povo fluminense, autonomiza-se e reaparece em A pátria brasileira, agora na condição de herói nacional. A ferocidade que o inferiorizava e colocava sobre seus ombros e os de sua tribo as marcas da animalização - pelados e sem lei - torna-se virtude: substância da coragem, contribuição da raça indígena ao caráter nacional. Não se trata mais de expulsar o indígena para fora dos limites da civilização, mas de integrá-los como parte constitutiva do povo brasileiro:

[...] O litoral sul do Brasil guarda, em cada uma das suas angras, uma recordação de Cunhambebe. O nome do herói, que atrasou a colonização desta parte do Brasil, merece, apesar disso, ser lembrado, - porque Cunhambebe defendia com bravura os privilégios da sua raça - e a bravura é sempre digna de admiração. ${ }^{39}$

Enfim, os próprios sentidos assumidos pela palavra "civilização" nos dois livros já indicam quão abstrata, plástica e imaginária é esta

35 Grifo do autor.

36 BILAC, O.; COELHO NETO. Contos pátrios. op. cit. p. 227.

37 Idem. A terrafluminense. op. cit., p.56.

$3^{8}$ Idem, ibidem, p.58.

39 Idem. A pátria brasileira. p. 93 
categoria. Conforme explicou Jean Starobinski ${ }^{40}$, na modernidade, civilizar assume o sentido figurado de polir, tanto os homens quanto os objetos: "polir é civilizar os indivíduos, suas maneiras, sua linguagem". A civilidade, explica ainda Starobinski, é a face externa da polidez, das estruturas internas que determinam a ação dos indivíduos. Nesse processo, o polimento educativo aparece como instância civilizadora, cuja ação recai sobre todos aqueles que, de alguma forma, necessitam da transformação: crianças, jovens, bárbaros, provincianos etc.

Para assinalar o alcance da transfiguração cívica, insistamos um pouco mais nos sentidos atribuídos à civilização em A terra fluminense e em Contos pátrios. No primeiro, é a criança fluminense que sofre a ação do polimento educativo. O público escolar infantil recebe noções de história, de condutas exemplares, das vantagens do progresso, das locomotivas e das indústrias. À medida que conhece os valores da civilização, constrói a imagem daquilo que não é civilização, ou seja, a barbárie, a selvageria, o índio. É o polimento educativo interiorizando hábitos civilizados no cidadão fluminense. Já no segundo, além de todos os elementos constitutivos da grosseria e do rudimentar que marcam a vida dos que ainda não passaram pelas escolas, os valores provincianos também são abarcados na lista de candidatos à transformação polida. As transfigurações do texto e a mudança do foco narrativo (do regional ao nacional) transformaram o amor à terra fluminense em sentimento incivilizado, sujeito, portanto, ao polimento pedagógico da pátria brasileira.

A técnica de reformulação literária parece mesmo ter caído no gosto dos príncipes das letras. A desfiguração operada nos ensinamentos cívicos de A terra fluminense atingiu outro conto. Desta vez foi a história do exescravo pai João. O título, evidentemente, foi alterado: antes O velho trabalhador, depois Uma vida. Aliás, esse procedimento, trocar títulos, corrigir texto e publicá-los como originais em livros de maior envergadura comercial, foi empregado também em $O$ colono, renomeado Pátria nova.

A narrativa sobre pai João apresenta transfigurações que evidenciam ainda mais o meticuloso, cauteloso e detalhado trabalho de relançamento dos textos de Bilac e Coelho Neto.

No alto do morro, que demorava a cavaleiro da fazenda, ficava a casinha do velho preto, do velho e meigo João, tão velho que não podia andar, e que já todos os seus dentes tinham caído.

40 STAROBINSKI, Jean. As máscaras da civilização: ensaios. São Paulo: Companhia das Letras, 1996. p. 28. 
A casa era como uma toca, entre árvores velhas como ele, no meio da verdura das folhagens abrigavam carinhosamente aquele centenário, a quem a morte parecia haver esquecido no lindo recanto do sertão fluminense. ${ }^{41}$

Em Contos pátrios o texto foi reescrito da seguinte forma:

No alto do morro, que demorava a cavaleiro da fazenda, ficava a casinha do velho preto, do velho e meigo pai João, tão velho que não podia andar, e que já todos os seus dentes tinham caído.

A casa era como uma toca, entre árvores velhas como ele, no meio da verdura das folhagens abrigavam carinhosamente aquele centenário, a quem a morte pareia haver esquecido no lindo recanto da terra brasileira ${ }^{42}$

As sutis alterações revelam duas preocupações de natureza e ordem diferentes. Primeiramente, a caracterização de Pai João (antes apenas João) logo nas primeiras linhas da narrativa. Uma desatenção, um erro de digitação, talvez, ou uma inserção deliberada. De todo modo, ratifica a hipótese, que temos trabalhado até aqui, de que o texto passou por um pente fino geral. Em segundo lugar, e mais importante, a já propalada intenção de se apropriar do texto produzido com a finalidade da educação cívica de caráter regional. Pai João mora num lindo recanto do sertão fluminense. Com a ampliação do foco narrativo do regional passando por uma nacionalização dos autores, do texto e da própria noção de pátria, Pai João permaneceu habitando um lindo recanto. Este recanto, porém, poderia ocupar o espaço geográfico do sertão fluminense, do sertão nordestino, do cerrado goiano, das serras mineiras, dos pampas gaúchos ou da floresta amazônica, conquanto fosse na terra brasileira.

As transfigurações operadas em Um velho trabalhador são importantes ainda por revelarem detalhes da articulação do corpo textual aos protocolos de leitura. Entre a página de rosto e o prefácio de $A$ terra fluminense há uma "nota", pela qual os autores orientavam os leitores, em particular os professores, às maneiras imprescindíveis de como se praticar uma boa leitura. A pequena mensagem em sua integralidade dizia o seguinte: "O professor chamará a atenção dos alunos para as palavras em grifo, explicando-as. ${ }^{\prime 3}$

\footnotetext{
41 BILAC, O.; COELHO NETO. A terra fluminense. op. cit., p. 23.

42 Idem. Contos pátrios. op. cit., p. 207.

43 Idem. A terra fluminense. op. cit., p. o2.
} 
Palavras grifadas assumiam importância diferenciada, em geral, por se tratar de um vocabulário julgado por demais complexo para crianças. A supressão de uma dessas palavras, porém, sugere motivações também de outra natureza. O quarto parágrafo foi originalmente escrito assim:

Eram as crianças da fazenda que lhe traziam comida: e pai João, comendo, ia com a voz fraca dizendo histórias ingênuas, que os pequenos escutavam com delícia. Depois dormia, à sombra enquanto a viração embalava docemente as arvores e as borboletas revoavam sobre a cabeça do velho ancião. Parecia o gênio tutelar da fazenda, aquele bom velho, que a vira nascer, crescer e prosperar. ${ }^{44}$

Do parágrafo, a palavra que sobressai é ancião, uma característica de João. Seguindo à risca as orientações normativas para uma leitura, o professor de educação cívica poderia interromper a leitura neste ponto, indagar à classe se todos sabem o que quer dizer ancião e, para reforçar uma opinião ou corrigir os comentários equivocados, apanhar um dicionário, postá-lo sobre a mesa e ler o significado do verbete. Nosso professor imaginário encontraria em ancião uma duplicidade, podendo ser adjetivo ou substantivo:

Ancião: adj. de provecta idade, de muitos annos fallando de pessoas, particularmente veneráveis e de autoridades.

Ancião: s.m. Homem (ou mulher) de provecta idade, mas com autoridade; Velho respeitável, digno de veneração pelas suas qualidades [...] As pessoas de maior idade e auctoridade de algum povo, logar, ou corporação, e às vezes do seu conselho ou governo. ${ }^{45}$

Pai João, o velho ancião, seria então um personagem importante, desempenhando papel político relevante, retendo o saber e influindo nos rumos da terra fluminense; homem respeitável e de apurado domínio das letras. Essas características, evidentemente, contrastavam com a biografia do ex-escravo. A imagem traçada é bem clara: "pobre, preto e ignorante"46, que guardava na memória o passado e o presente de uma propriedade particular no interior, onde vivia nas profundezas do seu isolamento e

44. Idem, ibidem, p. 24

45 SILVA, Antônio Moraes. Diccionário da língua portugueza. 8. ed. Rio de Janeiro: Empreza Litterária Fluminense, 1889. v. 1, p. 172.

${ }_{4} 6$ Passagens reproduzidas em BILAC, O.; COELHO NETO. A terrafluminense. op. cit. p. $25 \mathrm{e}$ Contos pátrios. op. cit., p. 211. 
passividade, frente ao processo de exploração ao qual foi submetido. Ancião era tão somente o adjetivo para um velho desvalido. A ambigüidade da palavra ancião possibilitava ainda a seguinte indagação: sendo respeitável e sábio, poderia o ancião contar histórias ingênuas? A passagem do século XIX ao XX e a republicação do texto resolveram o imbróglio:

Eram as crianças da fazenda que lhe traziam comida: e pai João, comendo, ia com a voz fraca dizendo histórias ingênuas, que os pequenos escutavam com delícia. Depois dormia, à sombra enquanto a viração embalava docemente as árvores e as borboletas revoavam sobre as flores silvestres. Parecia o gênio tutelar da fazenda, aquele bom velho, que a vira nascer, crescer e prosperar. ${ }^{47}$

Com sutileza, o termo carregado de sentido histórico (ancião), ambivalente e, portanto, suscetível a interpretações contraditórias, foi substituído por uma expressão a-histórica, pertencente ao mundo da natureza e muito apropriado ao Brasil-natureza que marcara o ufanismo na Primeira República. A nova fórmula - "borboletas revoavam sobre as flores silvestres"- dispensava plenamente as recomendações da nota introdutória. Por não estarem grifadas, não requeriam atenção diferenciada; por serem fenômenos da natureza, desfaziam as ambivalências, transformando-se no máximo em objeto de admiração ou contestação poética.

Peguemos um derradeiro exemplo. No conto "No Paraguai”, é possível antever todos os ingredientes que fizeram do conflito referência exemplar de patriotismo: o envelhecido ex-soldado paralítico, cercado de crianças, narrando as gloriosas lutas contra as forças comandadas por Solano Lopes, os ataques inimigos, o território adverso, a convicção patriótica, batalhas vencidas e perdidas e, enfim, o triunfo da nação brasileira. Agrupados inicialmente em uma única narrativa, esses temas alçaram vôos solos, ganharam autonomia, sendo relançados sob os títulos A pátria, O recruta, O perna de pau, em Contos pátrios e Guerra no Paraguai, Retirada de Laguna, Aquidabã, de A pátria brasileira.

As evidências não diminuem a importância das publicações posteriores a A terra fluminense, apenas realçam a importância desse livro, que, em matéria de educação cívica, constitui o discurso preliminar, espécie de roteiro geral que subsidiou a produção de outros textos cívicos dos mesmos autores. Desse modo, quando convidados pela Editora Francisco Alves para escrevem um livro infantil de viés cívico, os futuros príncipes, como intuitivamente suspeitou Lajolo, "tinham na gaveta ou

47 Idem, ibidem, p. 209-210. 
na cabeça os rascunhos da antologia". Na verdade, justiça às pistas analíticas seja feita, muitos dos textos publicados em Contos pátrios não eram originais, assim como textos e temáticas narradas em A pátria brasileira não passaram de desdobramento discursivo de livro anterior. A Imprensa Nacional os publicou, em 1898, em A terra fluminense. Com outros títulos e algumas modificações/correções vieram a compor o repertório dos Contos. Quando interpretados em seus contextos de publicações originais compõem um conjunto de discursos cívicos amplamente carregados das tensões geradas em torno da República Federativa.

Há de se indagar, por fim, se a Editora Francisco Alves, com as dimensões e importância que ocupava no mercado editorial de livros didáticos, desconheceria publicações de outra editora de igual ou maior gabarito, como era o caso da Imprensa Nacional. Se sim, a Editora foi vítima de uma marota peça pregada pelos jovens escritores. Assim se explicaria, então, a rapidez com que os dois produziram Contos pátrios. Quer dizer, adequaram alguns textos. Mas, pondo em dúvida a existência de tamanha ingenuidade por parte da Editora Francisco Alves, pode-se crer na probabilidade de um acordo tácito entre escritores e editores. Neste caso, os textos de $A$ terra fluminense reeditados em Contos pátrios e A pátria brasileira percorreram uma trajetória semelhante à história do Hino à Bandeira.

O hino à bandeira nacional surgiu de uma sugestão do Dr. Francisco Pereira Passos, que em 1905 ocupava o cargo de prefeito do Distrito Federal. Esse ilustre administrador pediu a Olavo Bilac que compusesse um poema em homenagem à Bandeira, encarregando o professor Francisco Braga da Escola Nacional de Música, de criar uma melodia apropriada à letra.

No ano seguinte, o hino foi adotado pela prefeitura do Distrito Federal, passando desde então a ser cantado em todas as escolas do Rio de Janeiro. Aos poucos sua execução estendeu-se às corporações militares e às demais unidade da federação, transformandoo, extra-oficialmente no hino à bandeira nacional, conhecida de todos os brasileiros. ${ }^{48}$

A Capital da República funcionou, nesses casos, como a matriz produtora de representações nacionais. Melhor seria dizer que o Distrito Federal foi um verdadeiro laboratório da alquimia cívica. A diferença é que, enquanto o Hino à Bandeira seguiu um sinuoso, mas transparente, percurso

48 MICHALANY, Sylvio. Enciclopédia de Educação moral cívica e política. São Paulo: Ed. Grandes enciclopédias da vida, 1971. p. 327-328. 
até o reconhecimento oficial, alguns textos de educação cívica, consagrados como representação de uma época, optaram pelo atalho da marotagem.

As semelhanças entre as publicações conduzem-nos, portanto, a interpretar os destinos do texto de $A$ terra fluminense, no sentido proclamado por David Harlan ${ }^{49}$. Não é originalidade que interessa, mas os mecanismos que proporcionam a dispersão temporal e espacial do texto. No caso de $A$ terra fluminense, a dinâmica do civismo nacional promoveu essa dispersão. O conteúdo do livro comportava dimensões múltiplas, tanto para a idéia de educação cívica, como para a noção de pátria. Os traços culturais que o compuseram partiram, pois, de focos ambíguos. Por isso mesmo, quando um dos focos da cultura se impôs, o diálogo entre terra fluminense e terra brasileira foi interrompido, proporcionando o nascimento de outro tipo de texto. Por Bilac e Coelho Neto deixaram de passar os múltiplos sentidos de civismo, fazendo emergir identidades nacionais do objeto antes marcadamente regional.

Deve lembrar-se o leitor de que a análise do prefácio de $A$ terra fluminense desencadeou exame mais profundo sobre as transfigurações do discurso cívico na produção didática de Olavo Bilac e Coelho Neto. É também a leitura do prefácio de Poesias infantis que proporciona o epílogo de nosso artigo. Foi nele que Olavo Bilac reconheceu a dificuldade de evitar repetições de frases, estilo e feições de outros livros. O que permite ir além, concluindo que ele, sutilmente, lançou pistas acerca das transfigurações cívicas presentes em Contos pátrios e A pátria brasileira:

Quando a casa Alves \& C me incumbiu de preparar este livro para uso das aulas de instrução primária, não deixei de pensar, com receios, nas dificuldades grandes do trabalho. Era preciso fazer qualquer coisa simples, acessível à inteligência das crianças; a quem vive de escrever, vencendo dificuldades de forma, fica viciado pelo hábito de fazer estilo. Como perder o escritor a feição que já adquiriu, e as suas complicadas construções de frase, e o seu arsenal de vocábulos peregrinos, para se colocar ao alcance da inteligência infantil?50

49 HARLAN, David. A história intelectual e o retorno da literatura. In: RAGO, Margareth; GIMENES, Renato Aloizio de Oliveira (Orgs.) Narrar o passado, repensar a história. Campinas: Unicamp, 200o, p. 15-62.

5o BILAC, Olavo. Ao leitor. op. cit., p. 273. 